\title{
Decision Making in Translation: Translator's Strategies and Decision Models for Rich Points in Titles
}

\author{
Lyudmila V. ENBAEVA' 1 (1)
}

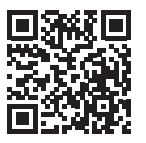

${ }^{1} \mathrm{PhD}$ in Philology, Perm State PedagogicalHumanitarian University, Department of Methods of Foreign Languages Teaching, Perm-Russia

ORCID: L.V.E. 0000-0003-4782-3744

\section{Corresponding author:}

Lyudmila V. ENBAEVA,

Perm State Pedagogical-Humanitarian University, Faculty of Foreign Languages, Department of Methods of Foreign Languages Teaching, 614019, Pushkina st. 42, Perm, Russia

E-mail: I.v.enbaeva@gmail.com;

I.v.enbaeva@pspu.ru

Submitted: 30.10 .2020

Revision Requested: 12.12 .2020

Last Revision Received: 06.05.2021 Accepted: 27.09.2021

Citation: Enbaeva, L. V. (2021). Decision making in translation: Translator's strategies and decision models for rich points in titles. Litera, 31(2), 811-833. https://doi.org/10.26650/LITERA2021-833571

\begin{abstract}
Recent developments regarding translation competence have led to the acknowledgement of the strategic role of decision making in the translation process. Researchers in different science fields have always seen problem-solving as an intrinsic part of any cognitive activity. The specific character of translation decision making is a challenging area of research which is primarily associated with the essence of the translation problem and strategies to solve it. The paper addresses translation decision strategies with the aim of classifying them and proposing clusters of translation decision models for problematic text elements collectively called Rich Points. The classification was verified on a corpus of 160 newspaper titles of articles published between July and August 2020 and translated into Russian. The correlation between the source text and target text (TT) Rich Point patterns afforded ground for proposing a set of translation decision models. Quantitative assessment of Rich Points frequency revealed a tendency to eliminate them in the TT. However, translation decision strategies and assessment of models productivity rate revealed it was due to the translators' loyalty towards factual information. The results suggest that although translation problems involve meaning disintegration, they can demonstrate patternlike nature, and pattern recognition seems to form the core of translation decision strategies and models.
\end{abstract}

Keywords: Translation decision, Rich Point, title, translation decision strategy, pattern recognition 


\section{Introduction}

Translation process is one of constant decision making as regards the analysis of the source language text, choice of the target language means and their rearrangement to construct a systemic unity of the target language text. Decision making is complex and needs specific consideration as a separate step of translation process especially when contingent on untranslatability cases, tropes, connotations, lexical gaps, linguistic variation or other problematic issues collectively called Rich Points. The term was introduced by PACTE research group (Universitat Autònoma de Barcelona) in their experimental research of Translation Competence (PACTE 2002, 2005). Rich Points are identified as source-text elements containing various translation problems. They are associated with linguistic and extralinguistic issues, with textual problems of translation, with problems of intentionality, and with translation brief. Additionally, they may be connected with the readers of the target text (Beeby, et al., 2009). These highlight certain problem-solving skills which are necessary for translators to have in order to deal with a multiplicity of translation options. Currently, global information density and its rate of growth require re-assessment and re-establishment of principal plurality of textual and cultural spaces. This overcomplicates the translation process and underscores the necessity to analyse the translator's decision making process and result.

The evolution of problem-solving as a theoretical concept and translation constituent can be traced down within the scholarship of translation studies over the last decades. This can be summarized as a movement from the research focus on translation variation and plurality towards the analysis of its cognitive bases and its incorporation into translation competence model.

The issue of translation plurality is of a two-fold nature as it embraces the underlying reasons for the existence of the phenomenon and those circumstances that dictate to the translator how to handle it. Fritz Guttinger analyses factors that cause translation plurality: different interpretation of the source text, meanings mismatch stipulated by language systems divergence, and translator's aims (Guttinger 1963). Among the circumstances determining the variety of translator's choice are translation tasks, chosen strategies, communicative situations, language and textual norms. Otto Kade allows for variation of language means chosen to accomplish a translation task provided these means align with the communicative situation (Kade 1968). Gideon Toury analyses those forces that directly affect the translator's choice. The focal point of his approach 
is the phenomenon of a set of norms that translation conforms to. Considering problemsolving as functionally related to translation norms, he suggests that the translator's decision and strategies are constrained by preliminary, operational and textual-linguistic norms; they operate in all kinds of translation and at each of the stages (Toury 1980). Researchers' acknowledgement of variation as a fundamental property of translation has led to the representation of the translator's task as choosing one option of many. This step led researchers to the description of problem-solving in translation as a cognitive process and to the admittance of its overall significance as an integral part of translation competence.

Wolfram Wills is one of those theorists who consider translation studies to be a cognitive science since it deals with cognitive operations. Therefore, the translation process should be described in terms of action models, problem-solving, creativity, strategies, etc. (Wilss 1982). He states that decision-making in translation is in fact a procedure of processing information that involves interaction of the translator's cognition, knowledge bases, task and the textual problem space (Wilss 1994). Lev K. Latyshev, Arkadiy L. Semyenov and Ryurik K. Minyar-Beloruchev agree on the strategic position of translation decision making in the translation process viewed as a system of cognitive operations. It implies a rational choice of strategies, techniques and language means (Latyshev\& Semyenov 2003; Minyar-Beloruchev 1999).

The research paper presenting the "results of the validation of the PACTE translation competence model" (Beeby, et al. 2009, p. 207) is a milestone in the theoretical interpretation of translation decision making. The researchers view problem-solving to be an intrinsic aspect of translation process and empirically demonstrate its pivotal role. According to the PACTE group empirical research results, the strategic subcompetence of translation competence comprises identifying problems and solving them. Decisions made during this process enfold the use of non-automatic and automatic cognitive resources as well as a variety of documentation sources. Thus the concept of decision making has rightfully acquired its place among the constituent elements of the translation competence model, the latter providing a comprehensive approach to efficient translation process representation (Beeby, et al. 2009, p.208). However, problemsolving strategies and action models require special attention.

The aim of the research was to analyze problem-solving in translation in order to classify strategies and propose a set of translation decision models for Rich Points in 
newspaper article titles thereby providing quantitative assessment of Rich Points frequency and translation decision strategies productivity rate which would give grounds to discuss reasons behind the translator's choice.

\section{Theoretical Background}

\subsection{Approaches to Problem Solving}

Problem-solving is considered one of the fundamental issues in cognitive sciences and a number of related interdisciplinary research spheres. The study of creative thinking brought Graham Wallas to formulate a four-step process of creativity: preparation, incubation, inspiration and verification (Wallas 1926). This idea was soon transformed into a wide discussion on creative problem-solving (CPS) framework development. The approaches were analysed retrospectively by Scott G. Isaksen and Donald J.Treffinger and grouped into 6 major versions of CPS. One of them is of interest for the current research since it is claimed to respond to the needs of cognitivist perspective. CPS version 5.1 includes the components of (1) problem understanding, (2) ideas generating, (3) preparing for acting, (4) task appraising and (5) process planning; they can be used in a variety of different orders or sequences and are viewed as cognitive processes (Isaksen \& Treffinger, 2004). George Pólya opened up a vista of research into teaching problem-solving skills by developing heuristic strategies and proposing four stages of heuristics: "(1) understanding the problem, (2) devising a plan, (3) carrying out the plan, (4) looking back" (Pólya 1957, p.8). He aimed his attention at teaching mathematics, but the ideas proved valuable for other problem-based spheres. The variety of ensuing studies was reviewed by Tim Passmore in (Passmore 2007). He summarized that heuristic training becomes valuable when the context of a particular problem-solving domain is set. He also highlighted the necessity of direct metacognitive training which can foster self-regulation and activity monitoring skills. Taking into consideration the cognitive aspects of the issue, John Mason, Leone Burton and Kaye Stacey (Mason, et al. 2011) proposed that there should be an increased emphasis on the metacognition skills of setting the goal, monitoring and problemsolving process assessment. It is necessary to note that problem- solving framework attracted researchers' attention also within problem-based learning (PBL) development and practice. The teaching method was first introduced into the curricula of US medical schools, then the ideas were applied in different teaching contexts, and PBL implementation now transcends scientific and instruction fields. John Dewey was 
among those who laid the foundation for the new pedagogy approach that would address reflective thought necessary to respond to a problem. A problem was viewed as an indeterminate situation (Dewey 1938). Tom Burke noted that this understanding of what constitutes a problem requires special attention since it was looked at through a broader lens and involved instances of "disequilibrium, instability, imbalance, disintegration, disturbance, dysfunction, breakdown, etc." (Burke 1994, p. 22). Thus the existing approaches to problem-solving in different science fields analyze its framework, phases, cognitive strategies, metacognitive skills and the essence of the problem per se.

\subsection{Problem Solving in Translation}

Translation is sometimes viewed as a process of translation problem-solving that comprises different strategies (Tijus 1997; Muñoz 1995; Padilla 1999; PACTE 2002, 2005, et al.). Translation problem is indeed a broad category of cases where two aspects can be differentiated for convenience: the textual domain and the translator's domain. The first comprises linguistic, textual and sociocultural phenomena, while the translator's actions, strategies and skills are analysed within the second domain. Thus the specific character of the translator's problem-solving or translation decision making is primarily associated with the essence of the translation problem as a textual element and with the special skills necessary to deal with it.

Translation problems are basically challenges or obstacles that impede or prevent translation. They can be described as possessing the above characteristics of disequilibrium and breakdown offered by Tom Burke; this is due to differences between languages and cultures that can cause disintegration of meaning during the process of translation. Factors that complicate the translation process can be generally of linguistic, textual or sociocultural nature. It is understood however that they vary, and the description of this broad range can be based on different principles. Joseph H. Danks grouped them into six types: vocabulary difficulty, style, translator's mental model, technical or conceptual difficulty, connotative meanings, translator's previous knowledge (Danks 1995). Katharina Reiss highlights those problematic cases which occur when text elements do not belong to the same type as the dominant text type and cases connected with retaining the artistic organization or operative effect (Reiss 2004). With the aim to collect data on decision-making the PACTE group categorized problematic items in the source text (ST) as "Rich Points" that possess three main characteristics: 
variety in the types of translation problems, unavailability of immediate solutions and homogeneity in different languages to provide for comparisons (PACTE 2005). Their identification of Rich Points was conducted with regard to five translation problem types: (1) linguistic; (2) textual; (3) extralinguistic; (4) problems of intentionality; (5) problems stipulated by the situation of translation performance (PACTE2009). This approach acknowledges variation of translation problems, fits Tom Burke's description of a problem that involves instances of disintegration, and permits the discarding of potential vagueness or inaccuracies of problematic case types distinguishing when the research focuses on the translator's actions rather than the nature of translation challenges.

The other aspect of translation problem-solving involves the actions, strategies and skills that a translator needs for decision making. The study of this aspect can be process-oriented or result-oriented. The first is analysed within the framework of translation process research (TPR) and employs laboratory-based methods: think-aloud protocols, screen recording techniques, eye trackers, neurological and neuroimaging tools. When the research is result-oriented, the ST and TT are compared with each other to induce what translation strategies were used. The current study analyses problemsolving strategies in correlation with the translation decision result. There are classifications of translation decisions strategies in general and strategies of solving specific translation problems. Katharina Reiss proposed three modes of translating aimed at functional equivalence: translation according to the sense and meaning, translating by identification with the creative intention of the author, and adaptive translating where some elements are replaced in order to fulfill the desired function (Reiss 2004). Alexandra A. Rosa proposed a spatial classification of strategies for translation decisions of linguistic variation: omission, addition, maintenance, change (Rosa 2012). Olga V. Kazakova (2006) pinpoints five types of translation strategies to deal with puns in literary translation: zero translation or translation by omission, literal translation, creating a similar artistic element, providing translator's comments in endnotes, offering in-text explanation or interpolation. The paper sets out to propose a classification of translation strategies to deal with Rich Points that would concur with the above approaches and will address different translation problems, will facilitate a combination of quantitative and qualitative analysis and will provide the basis for the discussion of reasons for the choice of strategies. 


\subsection{Translation of Titles}

Previous research on titles is abundant and covers issues of title typology, structure, length, impact on the reader, correlation between the article type and downloads, and translation strategies. An exhaustive review of research is given in (Farghal \& Bazzi 2017) and covers approaches to classifications of titles, their functions and translation strategies. Their analysis of book titles translation between English and Arabic involves assessment of distribution and frequency of translation procedures: adaptation, literal translation, transliteration, employment of related words, explication, paraphrase. Another substantial review of contributions to titles study is provided by Viviana Soler (Soler 2007) who reveals heterogeneity in the investigation of research paper titles and admits that genre-based data on titles are scarce. It should also be noted that scant attention has been given to problem-solving while working on title translation. One of the most relevant studies to the present article is a research paper by Kseniia V. Bogdanova (Bogdanova 2018). Her analysis of animated series titles with intertextual elements leads the author to the conclusion that interpreters opt for a less expressive translation decision in 365 out of 474 title translations. Another translator's option is a search for a different allusion that might be meaningful to the target language speakers. Kseniia V. Bogdanova admits this can be the result of interpreters' hierarchical approach to a title analysis when different levels of significance are attached to different senses. The function of the title to represent the text predominates and dictates the hierarchy of translation decisions. This conclusion is in line with Christiane Nord's functional translation approach which proposes that "the translator has to reconcile" the ST and TT by reestablishing text functions; as a text-type, 'titles are intended to achieve six functions: distinctive, metatextual, phatic, referential, expressive, and appellative' (Nord 1995, p. 261). The first three are essential and the rest are optional. The current paper presents the results of a genre-based study of news titles; it is focused on Rich Points occurrence in them.

\section{Material and Method}

\subsection{Material}

The study examined translation decision making in newspaper titles of articles published on a news web-portal http://inosmi.ru. The research selected 160 articles written in English and translated into Russian, published between July and September 
2020. Subcorpora included politics (titles with Rich Points are given in Appendix A), economics (Appendix B) and science (Appendix C). Continuous sampling was employed to ensure a broad range of subject matter and a natural ratio of Rich Points occurrence. The sample included 80,40 and 40 titles of articles on politics, economics and science respectively.

\subsection{Qualitative Analysis}

The significance of classification for decision making is demonstrated by Richard O. Duda, Peter E. Hart, David G. Stork in their seminal work on pattern classification. The researchers argue that this ability is crucial for people who have developed sophisticated cognitive systems to perform these actions (Duda, et al., 2012). They explain that "pattern recognition is the act of taking in raw data and making an action based on the category of the pattern" which is identified by segmentation, feature extraction, classification (Duda, et al., 2012, p.1). Thus we can assume that when a translator encounters a Rich Point, its pattern is identified by segmenting into meaning and functional aspects, extracting key features and categorizing. We can also assume that pattern recognition will affect the translation decision result.

A Rich Point is considered here to reveal a pattern-like nature which influences the translation process. The contents and form of a Rich Point in the ST are intended to make it prominent in the text. When this distinction is retained in the TT, it can correlate with the pattern of the Rich Point in the ST. This pattern is assumed to be based on the translation problem type. The PACTE research group chose six types of translation problems to identify a Rich Point: linguistic, extralinguistic, textual, intentionality-related; problems intrinsic in translation brief, or those predetermined by TT readers (Beeby, et al., 2009). Three patterns of Rich Points will be analysed in the current research: linguistic (lexical and morphosyntactic problems of translation), extralinuistic (cultural), intentionality-related (presuppositions, implicatures). In Example 1 the distinction of the phrase 'extraordinary powers' is due to lexical polysemy, different meanings are actualized: ability, political influence and authority. The translation problem can be categorized as a Rich Point of linguistic type (RPL). In Example 2 there is an allusion to an American film 'A Nightmare on Elm Street' (1984), and this is a Rich Point of extralinguistic type (RPE). In Example 3 the metaphoric use of the verb'race for'implies global endeavours to develop COVID-19 vaccines, so it can be identified as an intentionality related Rich Point (RPI). 
Example 1. Rich Point of linguistic type (RPL)

"Why is Putin credited with extraordinary powers?"

Example 2. Rich Point of extralinguistic type (RPE)

"The Nightmare on Pennsylvania Avenue"

Example 3. Intentionality related Rich Point (RPI)

"Russia races for vaccine as Covid-19 nonchalance spreads"

The analysis of the correlation between the source language semantic pattern and the translation decision can lead to a decision strategies classification. Let us assume that a Rich Point can be retained, eliminated or changed. Thus the following classification can be proposed:

- retaining strategy

- eliminating strategy

- compensating strategy

The retaining strategy implies direct semantic correlation between the source and the target language patterns of Rich Points. Translation decision allows for preserving full implication of the message as in the example of a Rich Pont of extralinguistic type both in the ST and TT (Example 4). In the eliminating strategy the retention of contents dominates and influences over the artistic effect and a Rich Point in the ST is omitted in the TT. In the given example an intentionality related Rich Point 'Soviet Salute' implies a welcoming gesture from the Soviet times and is left out in the translated text (Example 5). The compensating strategy leads to indirect correlation between the source and the target language patterns when the translator employs a Rich Point of a different pattern. These translation decisions may be described as leading to Eugene A. Nyda's dynamic equivalence (Nida 2004), aimed at fitting the receptor language, culture, context and audience notwithstanding factual or semantic changes. In the given example (Example6) the metaphor of a five-finger punch is an allusion to martial arts, it suggests that Chinese actions are as menacing as a kung fu technique of a five-finger death punch. The translation gives an allusion to Chinese politics towards Tibet; it is expressive but has no condemnatory colouring.

Example 4. Retaining Strategy

ST: "The Nightmare on Pennsylvania Avenue"

TT: “Кошмар на Пенсильвания-авеню”

Back translation: The Nightmare on Pennsylvania Avenue 
Example 5. Eliminating Strategy

ST: "A Soviet salute? Russian schools quick march towards more military training"

ТТ: “В российских школах возобновляют военную подготовку”

Back translation: In Russian schools military training is renewed

Example 6. Compensating Strategy

ST: "China's Five-Finger Punch"

ТТ: "Китайская стратегия пяти пальцев"

Back translation: Chinese strategy of five fingers

The qualitative analysis aims to find out whether it is possible to classify translation decisions as retaining, eliminating or compensating, and whether there is a correlation between a Rich Point type and translation decision strategy.

\subsection{Quantitative Assessment}

The evaluation included quantitative assessment of the number of Rich Points and their comparison with the corresponding translation decision results. Quantitative assessment was aimed at getting numeric data that would help measure changes associated with translation decision making. Rich Points coefficient $\mathrm{k}^{\mathrm{RP}}$ was found as frequency index:

$$
\mathrm{K}^{\mathrm{RP}}=\Sigma^{\mathrm{RP}} / \mathrm{N} \cdot 100 \%
$$

where $\Sigma^{\mathrm{RP}}$ is the number of Rich Points and $\mathrm{N}$ is the total number of titles in the sample. Coefficient $\mathrm{k}^{\mathrm{RP}} \mathrm{ST}$ was found for the source text and coefficient $\mathrm{k}^{\mathrm{RP}} \mathrm{TT}$ was found for the TT. The results were compared to find the difference between the frequency of Rich Points in the ST and the TT.

\section{Results}

\subsection{Qualitative Analysis Results}

The proposed classification of translation strategies was evaluated on a corpus of 160 titles of articles translated into Russian and published on news portal http://inosmi.ru. At the first stage Rich Points were identified in the ST and matched 
with the corresponding TT segments. At the second stage ST Rich Point patterns were identified by segmenting into meaning and functional aspects, and then TT features were extracted in order to deduce translation decision strategies for the analysed sample. Thirdly, the cases were grouped and classified according to the translation strategy that resulted in retaining, eliminating or changing of a Rich Point. Table 1 was used for convenience where RPL is a Rich Point of linguistic type, RPE is a Rich Point of extralinguistic type, RPI is an intentionality related Rich Point, RP0 is a zero Rich Point.

\begin{tabular}{|c|c|c|c|}
\hline \multirow[t]{3}{*}{ RP Translation Strategy } & \multicolumn{3}{|c|}{ RP Pattern of the Source Text } \\
\hline & RPL & RPE & RPI \\
\hline & \multicolumn{3}{|c|}{ RP Pattern of the Target Text } \\
\hline 1. Retaining & RPL & RPE & RPI \\
\hline 2. Eliminating & RPO & RPO & RPO \\
\hline 3. Compensating & & & \\
\hline a. 'meaning-bound' & RPOM & RPOM & RPOM \\
\hline b. 'function-bound' & RPLF & RPEF & RPIF \\
\hline
\end{tabular}

Contrary to expectations, the groups of the extracted translation decision models did not fully fit the proposed set of three strategies as the compensating strategy was actually better explained by subdividing it into two sub-strategies. The first was called a 'meaning-bound' compensating strategy to refer to the translator's decision not to change the factual meaning (Example 7). The second was called a 'function-bound' compensating strategy to refer to the translator's decision not to change the expressive function but to change the factual meaning (Example 8). A number of Rich Point patterns were added: the source text segment is translated according to the meaning and with a zero Rich Point (RPOM), the source text segment is translated with changes in the meaning and with an intention to retain a Rich Point and its function (RPLF, RPEF, RPIF).

Example 7.

ST: "Poverty Is a Choice" (RPI)

TT: “Бедность - это показатель выбранных данных" (RPOM)

Back translation: Poverty is a factor of chosen data

Example 8. 
ST: "Complacent Britain is a soft touch for Russia” (RPL)

TT: “Самодовольная Британия - слабое звено для России” (RPLF)

Back translation: Complacent Britain is a weak link for Russia

The RP Translation Strategy Grid (Table 1) was used to identify a number of translation decision models within the RP Translation Strategy classification (Table 2).

\begin{tabular}{|l|l|}
\hline \multicolumn{2}{|l|}{ Table 2. Models of Translation Decision } \\
\hline RP Translation Strategy & Translation Decision Models \\
\hline 1. $\quad$ Retaining & RPL-RPL, RPE-RPE, RPI-RPI \\
\hline 2. Eliminating & RPL-RPO, RPE-RPO, RPI-RPO \\
\hline 3. Compensating & \\
\hline a. 'meaning-bound' & RPL-RPOM, RPE-RPOM, RPI-RPOM \\
\hline b. 'function-bound' & RPL-RPLF, RPE-RPEF, RPI-RPIF \\
\hline
\end{tabular}

\subsection{Quantitative Analysis Results}

Quantitative assessment of the samples included finding the number of Rich Points, finding the frequency index $\mathrm{k}^{\mathrm{RP}}$ to determine how often they occur in the samples, and comparing between Rich Points frequency coefficients of the ST and TT: $k^{R P S T}$ and kPPTT (Table 3). The difference between the frequency rates of Rich Points in the ST and TT is visually represented in a bar chart (Fig.1).

\begin{tabular}{|l|l|l|l|l|l|l|}
\hline \multicolumn{6}{|l|}{ Table 3. Rich Points frequency } \\
\hline $\begin{array}{l}\text { Content } \\
\text { areas of } \\
\text { inosmi.ru }\end{array}$ & $\begin{array}{l}\text { No of titles in } \\
\text { the sample }\end{array}$ & $\begin{array}{l}\text { No of RP } \\
\text { in the ST }\end{array}$ & $\begin{array}{l}\text { No of RP } \\
\text { in the TT }\end{array}$ & $\begin{array}{l}\mathbf{k}^{\mathrm{RP}} \mathbf{\%}, \\
\%\end{array}$ & $\begin{array}{l}\mathbf{k}^{\mathrm{RP}} \mathrm{TT}, \\
\%\end{array}$ & $\begin{array}{l}\text { Difference } \\
\text { between } \mathbf{k}^{\mathrm{RP}} \mathbf{S T} \\
\text { and } \mathbf{k}^{\mathrm{RP} T T}\end{array}$ \\
\hline Politics & 80 & 42 & 24 & 52,5 & 30 & 22,5 \\
\hline Economics & 40 & 11 & 5 & 27,5 & 12,5 & 15 \\
\hline Science & 40 & 11 & 7 & 25 & 17,5 & 7,5 \\
\hline
\end{tabular}

The research found that the frequency rate of Rich Points ( ${ }^{\mathrm{RP} S T}$ ) is topic-related and is significantly higher for the subcorpus 'Politics'. The general tendency for the $\mathrm{k}^{\mathrm{RP} T T}$ is to decrease during translation. 


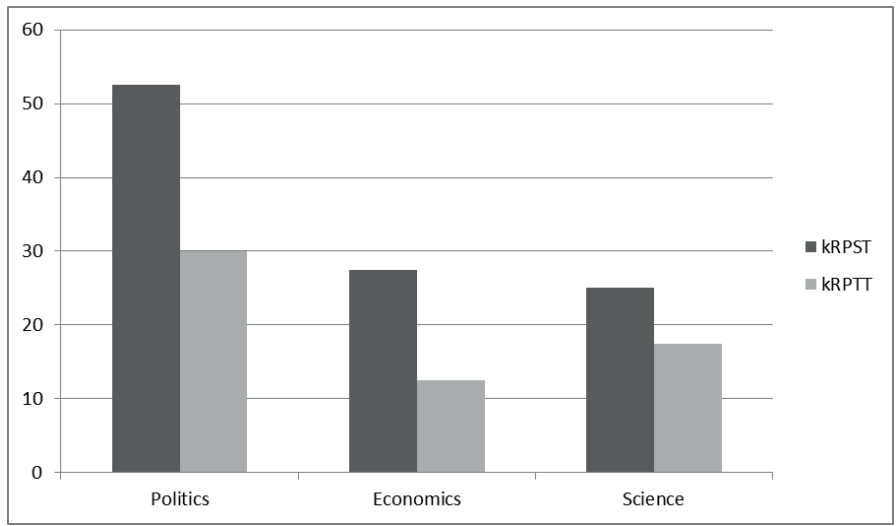

Figure 1. Difference between $\mathrm{k}^{\mathrm{RP}} \mathrm{ST}$ and $\mathrm{k}^{\mathrm{RP}} \mathrm{TT}$

It is seen that the difference between $\mathrm{k}^{\mathrm{RP} S T}$ and $\mathrm{k}^{\mathrm{RP} T T}$ is most pronounced for political news headlines and least for the science news articles. It can be assumed that translator's hierarchical approach to a title analysis resulted in attaching a higher level of significance to factual aspects rather than expressiveness.

Further analysis focused on translation decision models. These were counted for each of the three samples to assess the productivity (Table 4). The rate of productivity of translation models was found as a ratio of the model number relative to the total number of models employed in the samples obtained for analysis.

\begin{tabular}{|c|c|c|c|c|c|c|}
\hline \multirow[t]{2}{*}{ Strategy } & \multirow[t]{2}{*}{ Model } & \multicolumn{3}{|c|}{ Number of models } & \multirow{2}{*}{$\begin{array}{l}\text { Total } \\
\text { number }\end{array}$} & \multirow{2}{*}{$\begin{array}{l}\text { Rate of } \\
\text { productivity }\end{array}$} \\
\hline & & Politics & Economics & Science & & \\
\hline 1. Retaining & $\begin{array}{l}\text { RPL-RPL } \\
\text { RPE-RPE } \\
\text { RPI-RPI }\end{array}$ & $\begin{array}{l}5 \\
3 \\
11 \\
\end{array}$ & $\begin{array}{l}2 \\
1 \\
1\end{array}$ & $\begin{array}{l}3 \\
1 \\
3\end{array}$ & $\begin{array}{l}10 \\
5 \\
15 \\
\end{array}$ & $\begin{array}{l}0,16 \\
0,08 \\
0,24\end{array}$ \\
\hline 2. Eliminating & $\begin{array}{l}\text { RPL-RPO } \\
\text { RPE-RPO } \\
\text { RPI-RPO }\end{array}$ & $\begin{array}{l}2 \\
- \\
-\end{array}$ & $\begin{array}{l}1 \\
- \\
-\end{array}$ & $\begin{array}{l}3 \\
- \\
1\end{array}$ & $\begin{array}{l}5 \\
- \\
1\end{array}$ & $\begin{array}{l}0,08 \\
- \\
0,01\end{array}$ \\
\hline \multicolumn{7}{|l|}{ 3. Compensating } \\
\hline 'meaning-bound' & $\begin{array}{l}\text { RPL-RPOM } \\
\text { RPE-RPOM } \\
\text { RPI-RPOM }\end{array}$ & $\begin{array}{l}13 \\
- \\
3\end{array}$ & $\begin{array}{l}3 \\
- \\
2\end{array}$ & $\begin{array}{l}1 \\
- \\
-\end{array}$ & $\begin{array}{l}17 \\
- \\
5\end{array}$ & $\begin{array}{l}0,27 \\
- \\
0,08\end{array}$ \\
\hline 'function-bound' & $\begin{array}{l}\text { RPL-RPLF } \\
\text { RPE-RPEF } \\
\text { RPI-RPIF }\end{array}$ & $\begin{array}{l}3 \\
- \\
-\end{array}$ & $\begin{array}{l}1 \\
- \\
-\end{array}$ & $\begin{array}{l}- \\
- \\
-\end{array}$ & $\begin{array}{l}4 \\
- \\
-\end{array}$ & $\begin{array}{l}0,06 \\
- \\
-\end{array}$ \\
\hline Total number of models & & & & & 62 & \\
\hline
\end{tabular}


It can be observed from the data acquired that retaining and compensating strategies possess higher rates of productivity.

Rich Points of linguistic type quite predictably caused difficulties for translators, this resulting in a higher productivity rate for the model RPL-RPOM. It is interesting to note that the retaining strategy was used for all the Rich Points of extralinguistic type. Another observation that emerges from the data is that extralinguistic and intentionality related Rich Points more often 'survive' the translation than Rich Points of linguistic type.

It is evident from the data that the decrease in number of Rich Points found in the previous stage of analysis does not imply high rates of eliminating the productivity of decision models. This is actually due to the fact that translators opted for the'meaningbound' compensating strategy when the factual meaning of the Rich Point is retained and the expressiveness is lost. This result can further strengthen confidence in the translator's loyalty towards factual information.

\section{Discussion}

This research addressed the issue of translation problem-solving. It is assumed that explicit Rich Point pattern classification and comparison between their occurrence in the ST and TT can be employed to propose a set of translation decision strategies and models to deal with translation problems. The study put forward a combination of three strategies: retaining, eliminating and compensating. It was verified on a sample of 160 news article titles and their translations from English into Russian. At the first stage of the research a qualitative analysis was performed which included a comparison between the ST and TT Rich Points patterns. It revealed the necessity to extend the description of the compensating strategy by subdividing it into'meaning-bound'and 'function-bound' sub-strategies. In the first case compensation decision making is aimed at preserving the factual meaning notwithstanding the loss of expressiveness. The second perpetuates the expressive function notwithstanding the changes in factual meanings. The revealed correlation between the ST and TT Rich Point patterns laid the groundwork for translation decision models clustering. Some of the resulting translation decision models were found in the sample under analysis and some were not, but they can probably be traced down in texts of genres other than newspaper articles. The second stage of the research involved quantitative analysis of Rich Points frequency in the ST and TT and assessment of translation decision models productivity rate. It 
revealed that there was a general tendency to reduce the number of Rich Points during translation. Quite predictably Rich Points of linguistic type were difficult to retain and translators often used compensation or elimination. At the same time the decrease of Rich Points found in the previous stage of analysis was not due to high rates of eliminating decision models productivity but rather to the translators' choice of 'meaning-bound' compensation decision models premised on the translator's loyalty towards factual information. This finding is consistent with Kseniia V. Bogdanova's (Bogdanova 2018) observation that Russian translators of animated series titles opt for a less expressive translation decision, omitting or changing intertextual elements. It is also in agreement with Mohammed Farghal \& Hamidreza Bazzi's (Farghal \& Bazzi 2017) findings with regard to book title translating into Arabic where literal translation predominates. The present study only investigated newspaper titles for the content areas of politics, economics and science. Therefore, important limitations are genre related. Further data collection would be needed to determine translation decision models employed to deal with Rich Points in texts of different genres. The results of the study suggest that although translation problems (Rich Points) involve meaning disintegration and verge on untranslatability, they are not immune to classification, and pattern recognition seems to form the core of translation decision strategies. In this respect the research might have implications for the study of translation decision phases as regards Rich Points, automatic and non-automatic choice of models, principles of hierarchical approach to Rich Point's key features extraction within the framework of pattern recognition.

Peer-review: Externally peer-reviewed.

Conflict of Interest: The author has no conflict of interest to declare.

Grant Support: The author declared that this study has received no financial support.

Hakem Değerlendirmesi: Dış bağımsız.

Çıkar Çatışması: Yazar çıkar çatışması bildirmemiştir.

Finansal Destek: Yazar bu çalışma için finansal destek almadığını beyan etmiştir.

\section{References}

Beeby, A., Fernández, M., Fox, O., Albir, A., Kozlova, I., Kuznik, A., Neunzig W., Rodríguez, P., Romero, L., Wimmer, S. (2009). Results of the validation of the PACTE translation competence model: Acceptability and decision making. Across Languages and Cultures, 10(2), 207-230. 
Bogdanova K. V. (2018) Ways of conveying the properties of intertextual insertions when translating from English into Russian (based on the titles of episodes from English-language animated television series). Vestnik of Saint Petersburg University. Language and Literature, 15(3) 412-423. https://doi.org/10.21638/ spbu09.2018.307 (In Russian)

Burke, T. (1994). Dewey's new logic: A reply to Russell. University of Chicago Press.

Danks J. H. (1995): The psycholinguistics of reading and translation. In A. Neubert, G. Shreve, \& K. Gommlich (Eds.), Basic Issues in Translation Studies (pp. 101-112). Kent, OH: Institute for Applied Linguistics.

Dewey, J. (1938). Experience and education. New York: Macmillan.

Duda, R. O., Hart, P. E., \& Stork, D. G. (2012). Pattern classification. John Wiley \& Sons.

Farghal, M., Bazzi, H. (2017) Translation of English fiction titles into Arabic. The International Journal for Translation \& Interpreting Research, Vol. 9 No 2. DOI: 10.12807/ti.109202.2017.a08

Guttinger, F. (1963). Zielsprache. Theorie und Technik des Obersetzens. Zürich.

Isaksen, S. G., \& Treffinger, D. J. (2004). Celebrating 50 years of reflective practice: Versions of creative problem solving. The Journal of Creative Behavior, 38(2), 75-101.

Kade, O. (1968). Zufall und Gesetzmäßigkeit in der Übersetzung (Vol. 1). Verlag Enzyklopädie. Leipzig

Kazakova O.V. (2006). Osobennosti hudozhestvennogo perevoda [Translation: Specific Character of Literary Translation], Fenix publ., Rostov-on-Don.

Latyshev, L.K., Semyenov A.L. (2003) Perevod: teoriya, praktika i metodika prepodavaniya [Translation: theory, practice and teaching methods]. Academia Publ. Moscow.

Mason, J., Burton, L., \& Stacey, K. (2010). Thinking mathematically. Pearson Higher Ed.

Minyar-Beloruchev, R.K. (1999) Kak stat' perevodchikom [How you become a translator]. Gotika Publ. Moscow. Muñoz R. (1995). Lingüística para Traducir, Barcelona, Teide.

Nida, E. A. (2004). Principles of Correspondence. In L. Venuti (Ed.), The Translation Studies Reader. Routledge.

Nord C. (1995) Text-Functions in Translation: Titles and Headings as a Case in Point. Target. International Journal of Translation Studies, 7(2), 261 - 284. DOI: https://doi.org/10.1075/target.7.2.05nor

PACTE. (2002). Exploratory Tests in a Study of Translation Competence. Conference Interpretation and Translation, 4(2), 41-69.

PACTE. (2005). Investigating Translation Competence: Conceptual and Methodological Issues. Meta, 50(2), 609619.

Padilla, P., Bajo, M. T., \& Padilla, F. (1999). Proposal for a cognitive theory of translation and interpreting. Edizioni Università di Trieste. URL: https://www.openstarts.units.it/bitstream/10077/2213/1/04Padilla.pdf Passmore, T. (2007). Polya's legacy: fully forgotten or getting a new perspective in theory and practice? Australian Senior Mathematics Journal, 21(2), 44-53.

Pólya, G. (1957). How To Solve It: A new aspect of mathematical method. Princeton university press, 2014

Reiss, K. (2004) Type, kind and individuality of text: decision making in translation. In L.Venuti (Ed.), The Translation Studies Reader. Routledge. 
Rosa, A. A. (2012). Translating place: linguistic variation in translation. Word and Text, A Journal of Literary Studies and Linguistics, 2(02), 75-97.

Soler V. (2007) Writing titles in science: An exploratory study English for Specific Purposes 26 90-102

Tijus Ch. (1997). "Understanding for interpreting, interpreting for understanding." In Y. Gambier, D. Gile \& Ch. Taylor (Eds.). Conference Interpreting: Current Trends in Research (pp. 29-48). Amsterdam-Philadelphia, John Benjamins.

Toury, G. (1980). In search of a theory of translation. Porter Institute for Poetics and Semiotics, Tel Aviv University. Wilss,W. (1982). The science of translation problems and methods. Turbinge: Gunter Narr.

Wilss, W. (1994). A framework for decision-making in translation. Target. International Journal of Translation Studies, 6(2), 131-150.

Wallas, G. (1926). The art of thought. NY, USA: Harcourt Brace. 


\section{Appendix A}

Source Text (ST) and Translation Text (TT) Titles with Rich Points from the subcorpus 'Politics'

\begin{tabular}{|c|c|c|c|}
\hline & ST title & TT title and back translation (BT) & Model \\
\hline 1. & $\begin{array}{l}\text { The New York Times: "The } \\
\text { Nightmare on Pennsylvania } \\
\text { Avenue" }\end{array}$ & $\begin{array}{l}\text { TT: "Кошмар на Пенсильвания-авеню" } \\
\text { BT: "The Nightmare on Pennsylvania } \\
\text { Avenue" }\end{array}$ & RPE-RPE \\
\hline 2. & $\begin{array}{l}\text { Project Syndicate: “China } \\
\text { Plays the Iran Card" }\end{array}$ & $\begin{array}{l}\text { TT:"Китай разыгрывает иранскую карту" } \\
\text { BT:"China Plays the Iran Card" }\end{array}$ & RPI-RPI \\
\hline 3. & $\begin{array}{l}\text { The New York Times: “Trump } \\
\text { Attacks an Election He Is at } \\
\text { Risk of Losing" }\end{array}$ & $\begin{array}{l}\text { TT: "Трамп выступает с нападками на } \\
\text { выборы, которые рискует проиграть" } \\
\text { BT: "Trump Expresses Criticism of an Election } \\
\text { He Is at Risk of Losing" }\end{array}$ & RPL-RPOM \\
\hline 4. & $\begin{array}{l}\text { The Atlantic: "Poverty Is a } \\
\text { Choice" }\end{array}$ & $\begin{array}{l}\text { TТ:“Бедность — это показатель } \\
\text { выбранных данных" } \\
\text { BT:“Poverty Is a Factor of Chosen Data" } \\
\end{array}$ & RPI-RPOM \\
\hline 5. & $\begin{array}{l}\text { Financial Times: "Russia } \\
\text { satellite weapon test reignites } \\
\text { space arms race fears” }\end{array}$ & $\begin{array}{l}\text { TТ:“Испытания российского } \\
\text { противоспутникового оружия возродили } \\
\text { страх перед новой гонкой вооружений" } \\
\text { BT:"Russia satellite weapon test renews } \\
\text { space arms race fears" }\end{array}$ & RPL-RPOM \\
\hline 6. & $\begin{array}{l}\text { The Christian Science } \\
\text { Monitor: "The ultimate high } \\
\text { ground: Russia and US try to } \\
\text { set rules for space weapons" }\end{array}$ & $\begin{array}{l}\text { TТ: "Предельная высота: Россия и США } \\
\text { пытаются установить правила для оружия } \\
\text { в космосе" } \\
\text { BT: "The ultimate altitude limit: Russia and } \\
\text { US try to set rules for space weapons" }\end{array}$ & RPL-RPOM \\
\hline 7. & $\begin{array}{l}\text { CNN: "Trump turns into a } \\
\text { pussycat on all things Putin" }\end{array}$ & $\begin{array}{l}\text { TТ:"Когда дело касается Путина, Трамп } \\
\text { nревращается в nушuстого котенка" } \\
\text { BT: "Trump turns into a fluffy kitten on all } \\
\text { things Putin" }\end{array}$ & RPI-RPI \\
\hline 8. & $\begin{array}{l}\text { The New Yorker: "Why } \\
\text { America Feels Like a Post- } \\
\text { Soviet State" }\end{array}$ & $\begin{array}{l}\text { TТ:“Почему Америка кажется } \\
\text { постсоветским государством" } \\
\text { BT:"Why America Looks Like a Post-Soviet } \\
\text { State” }\end{array}$ & RPL-RPOM \\
\hline 9. & $\begin{array}{l}\text { FP:"Britain Is Botching This } \\
\text { Cold War Just Like the Last } \\
\text { One" }\end{array}$ & $\begin{array}{l}\text { TТ: “Эту холодную войну Британия } \\
\text { проигрывает России, как и предыдущую" } \\
\text { BT: "Britain Is Losing This Cold War to Russia } \\
\text { Just Like the Last One” }\end{array}$ & RPL-RPOM \\
\hline 10. & $\begin{array}{l}\text { The Guardian: "Liberalism } \\
\text { is facing a crisis and it's a } \\
\text { cop-out to blame China and } \\
\text { Russia, analyst claims" }\end{array}$ & $\begin{array}{l}\text { TТ: “Обвинения в адрес России и Китая } \\
\text { в кризисе либерализма - бегство от } \\
\text { действительности" } \\
\text { BT:To blame China and Russia for the crisis } \\
\text { of liberalism is a cop-out }\end{array}$ & RPL-RPL \\
\hline 11. & $\begin{array}{l}\text { Telegraph: Space wars: How } \\
\text { future battles will be fought } \\
\text { in orbit }\end{array}$ & $\begin{array}{l}\text { TТ: “Какими будут настоящие звездные } \\
\text { войны” } \\
\text { BT: What real Space wars will be like }\end{array}$ & RPE-RPE \\
\hline
\end{tabular}




\begin{tabular}{|c|c|c|c|}
\hline 12. & $\begin{array}{l}\text { The Wall Street Journal: "De } \\
\text { Havilland Saved Hollywood } \\
\text { From Stalin" }\end{array}$ & $\begin{array}{l}\text { TT:“Де Хэвилленд спасла Голливуд от } \\
\text { Сталина" } \\
\text { BT:“De Havilland Saved Hollywood From } \\
\text { Stalin” } \\
\end{array}$ & RPE-RPE \\
\hline 13. & $\begin{array}{l}\text { News Thump: "Government } \\
\text { to tackle obesity in UK by } \\
\text { giving nation } 50 \% \text { off at Pizza } \\
\text { Hut throughout August" }\end{array}$ & $\begin{array}{l}\text { ТТ: “Правительство поборется с } \\
\text { ожирением британцев, предоставив } \\
\text { им } 50 \% \text { скидку в пиццериях в течение } \\
\text { августа” } \\
\text { BT:"Government will stand up to/fight } \\
\text { against obesity in UK by giving nation 50\% } \\
\text { off at Pizza Hut throughout August” }\end{array}$ & RPL-RPLF \\
\hline 14. & $\begin{array}{l}\text { Financial Times: “US urged to } \\
\text { exploit cracks in Russia-China } \\
\text { relationship" }\end{array}$ & $\begin{array}{l}\text { TТ:“США призвали использовать } \\
\text { mрешины в российско-китайских } \\
\text { отношениях" } \\
\text { BT:“US urged to exploit cracks in Russia- } \\
\text { China relationship” }\end{array}$ & RPI-RPI \\
\hline 15. & $\begin{array}{l}\text { The Guardian: "Forget Putin, } \\
\text { it's (1) meddling by America's } \\
\text { (2) evangelical enforcer that } \\
\text { should scare us" }\end{array}$ & \begin{tabular}{|l|} 
TТ:“Забудьте про Путина, бояться надо \\
убежденных в своей правоте США” \\
BT:“Forget Putin, you should be scared of \\
the USA that are convinced of their rightness
\end{tabular} & $\begin{array}{l}\text { (1) RPL-RPO } \\
\text { (2) RPL-RPOM }\end{array}$ \\
\hline 16. & $\begin{array}{l}\text { Financial Times: "A hard } \\
\text { road ahead for Zelensky in } \\
\text { Ukraine" }\end{array}$ & $\begin{array}{l}\text { TТ:"Зеленского на Украине ожидает } \\
\text { mернистый nymь" } \\
\text { BT:“A thorny road ahead for Zelensky in } \\
\text { Ukraine” }\end{array}$ & RPI-RPI \\
\hline 17. & $\begin{array}{l}\text { Salon: "Get over your Russia } \\
\text { obsession, liberals: Vladimir } \\
\text { Putin's not responsible for } \\
\text { America's sorry state" }\end{array}$ & $\begin{array}{l}\text { TТ: “Либералы, забудьте про вашу } \\
\text { одержимость Россией: в плачевном } \\
\text { состоянии Америки виноват не Путин” } \\
\text { BT: “Get over your Russia obsession, liberals: } \\
\text { Vladimir Putin's not responsible for America's } \\
\text { sad condition” }\end{array}$ & RPL-RPOM \\
\hline 18. & $\begin{array}{l}\text { The American Interest: "Little } \\
\text { Green Men. Should the West } \\
\text { Be Worried About Belarus?" }\end{array}$ & $\begin{array}{l}\text { TT:"Маленькие зеленые человечки. Стоит } \\
\text { ли Западу беспокоиться о Белоруссии?" } \\
\text { BT:"Little Green Men. Should the West Be } \\
\text { Worried About Belarus?" } \\
\end{array}$ & RPI-RPI \\
\hline 19. & $\begin{array}{l}\text { Forbes: “Pompeo Takes Aim } \\
\text { At Russia Where It Hurts: } \\
\text { History” }\end{array}$ & $\begin{array}{l}\text { TТ: “Помпео бьет Россию по больному } \\
\text { месту: по ее истории” } \\
\text { BT: "Pompeo Hits Russia Where It Hurts: } \\
\text { History” } \\
\end{array}$ & RPL-RPL \\
\hline 20. & $\begin{array}{l}\text { The Times: "My Week: } \\
\text { Vladimir Putin” }\end{array}$ & $\begin{array}{l}\text { TТ:“Дневник Владимира Путина за } \\
\text { неделю” } \\
\text { BT:“Vladimir Putin's journal-book/diary/ } \\
\text { memoirs for a week” } \\
\end{array}$ & RPI-RPI \\
\hline 21. & $\begin{array}{l}\text { The Guardian: "(1)'White as } \\
\text { hell': Portland protesters } \\
\text { face off with Trump (2) but } \\
\text { are they eclipsing Black Lives } \\
\text { Matter?" }\end{array}$ & $\begin{array}{l}\text { TТ: “(1) «Чертовски белые»: протестующие } \\
\text { в Портленде меряются силами с Трампом } \\
\text { (2)” } \\
\text { BT:"(1)'White as hell': Portland protesters } \\
\text { face off with Trump (2)" }\end{array}$ & $\begin{array}{l}\text { (1) RPL-RPL } \\
\text { (2) RPL-RPO }\end{array}$ \\
\hline 22. & $\begin{array}{l}\text { Foreign Policy:"How to Ruin } \\
\text { a Superpower" }\end{array}$ & $\begin{array}{l}\text { TТ:“Как разрушить супердержаву” } \\
\text { BT:“How to Ruin a Super nation / empire / } \\
\text { country” }\end{array}$ & RPL-RPOM \\
\hline
\end{tabular}




\begin{tabular}{|c|c|c|c|}
\hline 23. & $\begin{array}{l}\text { Foreign Affairs: "The Future } \\
\text { of American Power. How } \\
\text { America Can Survive the Rise } \\
\text { of the Rest" }\end{array}$ & $\begin{array}{l}\text { TТ:“Будущее американского } \\
\text { великодержавия Как Америке пережить } \\
\text { «взлет» других государств" } \\
\text { BT:“The Future of American Power. How } \\
\text { America Can Survive the 'Take-off' / Rise of } \\
\text { the Rest" }\end{array}$ & RPI-RPI \\
\hline 24. & $\begin{array}{l}\text { The Washington Post : "AOC's } \\
\text { speech about Ted Yoho's } \\
\text { 'apology' was a comeback for } \\
\text { the ages" }\end{array}$ & $\begin{array}{l}\text { ТТ: “Речь Окасио-Кортес об «извинениях» } \\
\text { Теда Йохо как напоминание о том, чего } \\
\text { быть не должно” } \\
\text { “Ocasio-Cortez's speech about Ted Yoho's } \\
\text { 'apology' as a reminder of what should not } \\
\text { happen/occur/exist” }\end{array}$ & RPI-RPI \\
\hline 25. & $\begin{array}{l}\text { Financial Times: "Why is Putin } \\
\text { credited with extraordinary } \\
\text { powers?" }\end{array}$ & $\begin{array}{l}\text { TТ:“Почему Путину приписывают } \\
\text { чрезвычайные способности?” } \\
\text { BT: “Why is Putin credited with extraordinary } \\
\text { abilities?” } \\
\end{array}$ & RPL-RPOM \\
\hline 26. & $\begin{array}{l}\text { The Wall Street Journal: } \\
\text { "Moscow Isn't New Delhi's } \\
\text { Pal" }\end{array}$ & $\begin{array}{l}\text { TT:“Россия Индии не друг" } \\
\text { BT:“Moscow Isn't New Delhi's Friend" }\end{array}$ & RPL-RPL \\
\hline 27. & $\begin{array}{l}\text { The Hill: "How Russian } \\
\text { imperialism could bring down } \\
\text { Putin" }\end{array}$ & $\begin{array}{l}\text { TT:“Как имперская политика России могла } \\
\text { бы привести к свержению Путина” } \\
\text { BT:“How Russian imperialist politics could } \\
\text { lead to bringing down Putin” } \\
\end{array}$ & RPI-RPI \\
\hline 28. & $\begin{array}{l}\text { Washington Examiner: } \\
\text { "Comeback: Trump neck and } \\
\text { neck with Biden, } 45 \%-47 \% \text {, } \\
\text { approval equal with Obama's } \\
\text { in 2012" }\end{array}$ & $\begin{array}{l}\text { TТ: "Трамп идет вровень с Байденом при } \\
\text { рейтинге одобрения 45\%-47\% - как у } \\
\text { Oбамы в } 2012 \text { году" } \\
\text { BT: “Trump goes apace with Biden, 45\%- } \\
\text { 47\%, approval equal with Obama's in 2012" }\end{array}$ & RPL-RPOM \\
\hline 29. & $\begin{array}{l}\text { Project Syndicate: "China's } \\
\text { Five-Finger Punch" }\end{array}$ & $\begin{array}{l}\text { TТ: “Китайская стратегия nяти пальщев" } \\
\text { ВТ: Chinese strategy of five fingers }\end{array}$ & RPL-RPE \\
\hline 30. & $\begin{array}{l}\text { The Times: "Complacent } \\
\text { Britain is a soft touch for } \\
\text { Russia" }\end{array}$ & $\begin{array}{l}\text { TТ:"Самодовольная Британия - слабое } \\
\text { звено для Pоссии" } \\
\text { BT: Complacent Britain is a weak link for } \\
\text { Russia }\end{array}$ & RPL-RPLF \\
\hline 31. & $\begin{array}{l}\text { Financial Times: "Russia } \\
\text { races for vaccine as Covid-19 } \\
\text { nonchalance spreads" }\end{array}$ & $\begin{array}{l}\text { ТТ:“Россия спешно разрабатывает } \\
\text { вакцину на фоне распространения } \\
\text { беспечного отношения к covid-19” } \\
\text { BT: Russia hurriedly develops vaccine against } \\
\text { the background of nonchalant attitude to } \\
\text { covid-19 }\end{array}$ & RPI-RPOM \\
\hline 32. & $\begin{array}{l}\text { The Washington Post: "Tucker } \\
\text { Carlson slams New York } \\
\text { Times for planning to write } \\
\text { about him" }\end{array}$ & $\begin{array}{l}\text { TT: “Такер Карлсон обругал «Нью-Йорк } \\
\text { таймс» за планы написать о нем" } \\
\text { BT: “Tucker Carlson swore at New York Times } \\
\text { for planning to write about him” }\end{array}$ & RPL-RPOM \\
\hline 33. & $\begin{array}{l}\text { Foreign Policy: "There Is No } \\
\text { Arctic Axis" }\end{array}$ & $\begin{array}{l}\text { TT: "Арктической оси не существует" } \\
\text { BT: "There Is No Arctic Axis" } \\
\end{array}$ & RPI-RPI \\
\hline 34. & $\begin{array}{l}\text { Wired: "Russia (1) blazed a } \\
\text { trail for Chinese oligarchs to } \\
\text { (2) nab London property" }\end{array}$ & $\begin{array}{l}\text { TТ:“Россия (1) проторила дорогу } \\
\text { китайским олигархам (2) к скупке } \\
\text { лондонской недвижимости” } \\
\text { BT:"Russia (1) blazed a trail for Chinese } \\
\text { oligarchs to (2) buy London property” } \\
\end{array}$ & $\begin{array}{l}\text { (1) RPI-RPI } \\
\text { (2) RPL-RPOM }\end{array}$ \\
\hline
\end{tabular}




\begin{tabular}{|c|c|c|c|}
\hline 35. & $\begin{array}{l}\text { Politico: "Russia's corona } \\
\text { euphoria”" }\end{array}$ & $\begin{array}{l}\text { TТ:“Коронавирусная эйфория России” } \\
\text { BT:“Russia's coronavirus euphoria”" }\end{array}$ & RPI-RPOM \\
\hline 36. & $\begin{array}{l}\text { Financial Times: "Turkey (1) } \\
\text { fuels regional (2) power game } \\
\text { over Mediterranean gas } \\
\text { reserves" }\end{array}$ & $\begin{array}{l}\text { TТ: "Турция (1) разжигает (2) силовую игру } \\
\text { за месторождения газа в Средиземном } \\
\text { море" } \\
\text { BT:"Turkey (1) fuels / starts (2) power game } \\
\text { over Mediterranean gas reserves" }\end{array}$ & $\begin{array}{l}\text { (1) RPL-RPL } \\
\text { (2) RPL-RPL }\end{array}$ \\
\hline 37. & Foreign Policy: "Putin's Folly" & $\begin{array}{l}\text { TТ:"Блажь Путина" } \\
\text { BT:"Putin's whim / extravagancy" }\end{array}$ & RPL-RPLF \\
\hline
\end{tabular}

\section{Appendix B}

Titles with Rich Points from the subcorpus 'Economics'

\begin{tabular}{|c|c|c|c|}
\hline & ST title & TT title and back translation (BT) & Model \\
\hline 1. & $\begin{array}{l}\text { Politico: "6 ways Germany } \\
\text { could kill the Nord Stream } 2 \\
\text { pipeline" }\end{array}$ & $\begin{array}{l}\text { TT: “6 способов, которыми Германия } \\
\text { может поставить крест на «Северном } \\
\text { потоке-2»” } \\
\text { BT:“6 ways Germany could put an end to the } \\
\text { Nord Stream } 2 \text { pipeline” }\end{array}$ & RPL-RPLF \\
\hline 2. & $\begin{array}{l}\text { Bloomberg: "Merkel's Russian } \\
\text { Pipeline Dilemma Laid Bare } \\
\text { by Poisoning Uproar" }\end{array}$ & $\begin{array}{l}\text { TТ: “Ситуация с отравлением Навального } \\
\text { обнаружила дилемму, с которой } \\
\text { столкнулась Меркель в связи с } \\
\text { российским газопроводом” } \\
\text { ВT:The situation with poisoning Navalniy } \\
\text { revealed a dilemma faced by Merkel in } \\
\text { connection with Russian Pipeline }\end{array}$ & RPI-RPOM \\
\hline 3. & $\begin{array}{l}\text { Eurasianet: "Chinese } \\
\text { hydroelectric investments in } \\
\text { Central Asia: A snapshot" }\end{array}$ & $\begin{array}{l}\text { ТТ:“Китайские инвестиции в Центральной } \\
\text { Азии: гидроэнергетика” } \\
\text { BT:“Chinese investments in Central Asia: } \\
\text { hydroenergetics” }\end{array}$ & RPL-RPO \\
\hline 4. & $\begin{array}{l}\text { The Financial Times: "Belarus's } \\
\text { skilled population will be a } \\
\text { boon if its economy opens } \\
\text { up" }\end{array}$ & $\begin{array}{l}\text { TТ:"Квалифицированное население } \\
\text { Белоруссии будет востребовано, если } \\
\text { экономика страны станет открытой" } \\
\text { BT:"Belarus's skilled population will be in } \\
\text { demand if its economy opens up" }\end{array}$ & RPL-RPOM \\
\hline 5. & $\begin{array}{l}\text { Ars Technica: "Russia's space } \\
\text { leader blusters about Mars in } \\
\text { the face of stiff budget cuts" }\end{array}$ & $\begin{array}{l}\text { ТТ: "Глава Роскосмоса хвастливо } \\
\text { рассуждает о Марсе на фоне } \\
\text { значительных бюджетных сокращений” } \\
\text { BТ:"Russia's space leader boastfully } \\
\text { discusses Mars in the face of stiff budget } \\
\text { cuts" }\end{array}$ & RPL-RPL \\
\hline 6. & $\begin{array}{l}\text { The Economist: "Economic } \\
\text { forecasts are too rosy. That } \\
\text { can be costly" }\end{array}$ & $\begin{array}{l}\text { TT: “Экономические прогнозы слишком } \\
\text { позитивны. Это может дорого обойтись” } \\
\text { BT: “Economic forecasts are too positive. That } \\
\text { can be costly” }\end{array}$ & RPL-RPOM \\
\hline
\end{tabular}




\begin{tabular}{|c|c|c|c|}
\hline 7. & $\begin{array}{l}\text { Project Syndicate: "Revisiting } \\
\text { the White Swans of } 2020 \text { " }\end{array}$ & $\begin{array}{l}\text { TT:“Ещё раз о белых лебедях } 2020 \text { года” } \\
\text { BT:“Once more about the White Swans of } \\
\text { 2020” }\end{array}$ & RPI-RPI \\
\hline 8. & $\begin{array}{l}\text { Forbes: "Will The Gold Price } \\
\text { Crash Or Shine This Week?" }\end{array}$ & $\begin{array}{l}\text { ТТ: “Что будет с ценой на золото на этой } \\
\text { неделе?" } \\
\text { ВТ:"What will happen to the gold price this } \\
\text { week?" }\end{array}$ & RPI-RPOM \\
\hline 9. & $\begin{array}{l}\text { The National Interest: "Will } \\
\text { Russia Weaponize Its Wheat } \\
\text { As the World Combats the } \\
\text { Coronavirus?" }\end{array}$ & $\begin{array}{l}\text { ВТ: "Станет ли пшеница оружием России, } \\
\text { пока мир борется с коронавирусом?” } \\
\text { TT: "Will Wheat become Russia's Weapon } \\
\text { While the World Combats the Coronavirus?" }\end{array}$ & RPL-RPOM \\
\hline 10. & $\begin{array}{l}\text { Foreign Policy: "Russia } \\
\text { Loosens Its Belt" }\end{array}$ & $\begin{array}{l}\text { TТ: “Россия ослабляет свой пояс" } \\
\text { BT: "Russia Loosens Its Belt" }\end{array}$ & RPE-RPE \\
\hline 11. & $\begin{array}{l}\text { Financial Times: "Russia's } \\
\text { amateur investors fuel stock } \\
\text { market trading boom" }\end{array}$ & $\begin{array}{l}\text { TТ:"Российские инвесторы-любители } \\
\text { подогревают торговый бум на фондовой } \\
\text { бирже” } \\
\text { BT:"Russia's amateur investors warm up / } \\
\text { heat up stock market trading boom” }\end{array}$ & RPL-RPL \\
\hline
\end{tabular}

\section{Appendix C}

Titles with Rich Points from the subcorpus 'Science'

\begin{tabular}{|c|c|c|c|}
\hline & ST title & TT title and back translation (BT) & Model \\
\hline 1. & $\begin{array}{l}\text { Science: "Siberia's 'gateway } \\
\text { to the underworld' grows } \\
\text { as record heat wave thaws } \\
\text { permafrost" }\end{array}$ & $\begin{array}{l}\text { TТ:“Сибирская «дверь в потусторонний } \\
\text { мир» увеличивается из-за рекордной } \\
\text { жары и таяния вечной мерзлоты” } \\
\text { BT:"Siberia's 'gateway to the underworld' } \\
\text { grows because of record heat wave and } \\
\text { permafrost thawing” }\end{array}$ & RPI-RPI \\
\hline 2. & Nautilus: "Your Brain in Love" & $\begin{array}{l}\text { TT: “Когда ваш мозг влюблен” } \\
\text { BT: “When Your Brain is in Love” }\end{array}$ & RPI-RPI \\
\hline 3. & $\begin{array}{l}\text { CNN: "The AN-225: How the } \\
\text { Cold War created the world's } \\
\text { largest airplane" }\end{array}$ & $\begin{array}{l}\text { TT:"Ан-225 - самый большой самолет в } \\
\text { мире создали в годы холодной войны” } \\
\text { BT:"The AN-225 - the world's largest } \\
\text { airplane was created in the years of the Cold } \\
\text { War" }\end{array}$ & RPI-RPO \\
\hline 4. & $\begin{array}{l}\text { Foreign Policy: "This is Your } \\
\text { Brain. This is Your Brain as a } \\
\text { Weapon" }\end{array}$ & $\begin{array}{l}\text { TТ: "Вот ваш мозг. А вот ваш мозг как } \\
\text { оружие” } \\
\text { BT:“Here is your brain. And here is your brain } \\
\text { as a weapon” }\end{array}$ & RPI-RPI \\
\hline 5. & $\begin{array}{l}\text { Science: "How many hot } \\
\text { dogs can a person really scarf } \\
\text { down in } 10 \text { minutes?" }\end{array}$ & $\begin{array}{l}\text { TТ: “Сколько же можно проглотить хот- } \\
\text { догов за } 10 \text { минут?” } \\
\text { BT: "How many hot dogs is it possible to } \\
\text { swallow in } 10 \text { minutes?” }\end{array}$ & RPL-RPOM \\
\hline
\end{tabular}




\begin{tabular}{|c|c|c|c|}
\hline 6. & $\begin{array}{l}\text { Politico: "The great nutrient } \\
\text { collapse" }\end{array}$ & $\begin{array}{l}\text { ТТ: "Как воздух влияет на качество еды" } \\
\text { ВТ: "Нow the air influences the quality of } \\
\text { food" } \\
\text { Comment: The ST title alludes to a book by } \\
\text { Helena Bottemiller Evich. The TT title retains } \\
\text { the allusion as the book was published in } \\
\text { Russian with the title "How the air influences } \\
\text { the quality of food" }\end{array}$ & RPE-RPE \\
\hline 7. & $\begin{array}{l}\text { Forbes: "Mars Alert: Why } \\
\text { Three Spacecraft Must Leave } \\
\text { For The Red Planet Within } \\
\text { Weeks Or Miss Their Chance" }\end{array}$ & $\begin{array}{l}\text { TТ:"Почему три космических корабля } \\
\text { должны вылететь к Марсу в течение всего } \\
\text { пары недель, или они упустят свой шанс" } \\
\text { BT:Why three spacecraft must leave for Mars } \\
\text { within only a couple of weeks or they will } \\
\text { miss their chance" }\end{array}$ & RPL-RPO \\
\hline 8. & $\begin{array}{l}\text { Ars Technica: "Winamp's } \\
\text { woes: how the greatest MP3 } \\
\text { player undid itself" }\end{array}$ & $\begin{array}{l}\text { TТ:"Беды и горести Winamp: как } \\
\text { величайший MP3-плеер сам себя } \\
\text { уничтожил" } \\
\text { BT:"Trials and tribulations of Winamp: how } \\
\text { the greatest MP3 player undid itself" } \\
\end{array}$ & RPL-RPL \\
\hline 9. & $\begin{array}{l}\text { Ars Technica: "Russia's space } \\
\text { leader seems pretty bitter } \\
\text { about SpaceX's success" }\end{array}$ & $\begin{array}{l}\text { ТТ: “Глава Роскосмоса, похоже, крепко } \\
\text { завидует успехам «СпейсЭкс»” } \\
\text { BT: “Russia's space leader seems to be } \\
\text { bitterly envious of SpaceX's success" }\end{array}$ & RPL-RPL \\
\hline 10. & $\begin{array}{l}\text { The New York Times: } \\
\text { (1)"Going Viral, or Not, in the } \\
\text { Milky Way. Is the pandemic } \\
\text { a rehearsal for our own (2) } \\
\text { cosmic mortality" }\end{array}$ & $\begin{array}{l}\text { TТ: "(1) Прогреметь на весь Млечный путь } \\
\text { - или (2) погибнуть" } \\
\text { BT: "To roar across the Milky Way - or to die" }\end{array}$ & $\begin{array}{l}\text { (1) RPL-RPL } \\
\text { (2) RPL-RPO }\end{array}$ \\
\hline
\end{tabular}


